\title{
藻類の培養における発光ダイオードおよび半導体レーザーの利用
}

\author{
岡澤 敦司 \\ 大阪府立大学大学院 生命環境研究科 (†599-8531 大阪府堺市中区学園町1-1)
}

\section{Utilization of Light-Emitting Diodes and Laser for Algal Cultivation}

\author{
Atsushi OKAZAWA \\ Graduate School of Life and Environmental Sciences, Osaka Prefecture University, 1-1 Gakuen-cho, Naka-ku, Sakai, Osaka 599-8531
}

(Received July 29, 2016)

\begin{abstract}
Microalgae are drawing keen attention as alternative sources of sustainable energy or functional materials. Photobioreactors are suitable for the production of high-value-added materials by microalgae because those systems can minimize such uncertain factors as weather fluctuations that negatively affect production. On the other hand, the utilization of artificial light sources in the photobioreactors increase cost. Recently, light-emitting diodes (LEDs) and laser diodes (LDs) are expected to be effective light sources for plant production in closed systems: "plant factories". Even though LEDs and LDs can be adopted for photobioreactors, relatively few studies have compared the effects of LED or LD irradiation on the growth and productivity of microalgae with plants. This review summarizes the recent trials of the utilization of LEDs or LDs for algal culture.
\end{abstract}

Key Words: Cyanobacteria, Green algae, Laser diode, Light-emitting diodes, Photosynthetic bacteria

\section{1. はじめに}

石油に代わる再生可能エネルギー源，あるいは，機能 性食素材など有用物質の生産者として藻類が注目を集め ている，改めて述べるまでもないが，藻類は太陽光をエ ネルギー源として大気中の $\mathrm{CO}_{2}$ を固定し, 脂質, 炭水化 物あるいはタンパク質といった有用資源へと変換する。 いわゆる高等植物でも同様のことは可能だが，一般的に 藻類の方が増殖が速いため, 単位面積・単位時間あたり の収量に利があるとされている ${ }^{1)}$. 藻類を培養する場 合, コスト面からは太陽光を利用する開放系で行うこと が推奨される。燃料など安価で大量に必要とされる資源 の生産にはこの方法が用いられるが, このような開放系 での培養においては, 外部からの雑菌の持込みや天候不 順による生産量のばらつきが問題となる。一方, 医薬品 や機能性化学品といったような高付加価值物質の生産に おいて，量より質が問われる場合には，完全閉鎖系の フォトバイオリアクターが用いられる。この場合, 原理 的には環境制御による高効率生産を持続的に行うことが 可能であるが，太陽光を利用できるという藻類による物 質生産の最大の利点は犠牲になる。この品質とコストの トレードオフの関係は, 植物による物質生産をほ場と植 物工場で行う場合の比較においても同様である。

本特集の他の原稿で解説されているように, コストを 可能な限り削減したうえで, 高品質な商品を生産するこ とを目的として, 植物工場での発光ダイオード ( La-
ser-Emitting Diode: LED) や半導体レーザー (Laser Diode: LD)の利用の試みが数多くなされている。一方, 微細藻 類の培養におけるLEDやLD利用の試みは未だ限定的で ある2)。本稿では，LEDあるいはLDを用いた藻類の培養 に関する研究の状況を概説し, 今後の展望を考察する.

\section{2. 微細藻類の種類と色素}

\section{1 藍藻 (cyanobacteria)}

英語でbacteria(細菌)と表されることからもわかるよ うに, 藍藻は核をはじめとする明確な細胞内小器官をも たない原核生物である。進化的に植物の葉緑体の起源と なった生物と考えられており，植物と同じょうにクロロ フィルをもつ。しかし，クロロフィル分子種の組成が高 等植物とは異なっているため, 青色光の利用効率は悪い とされている。一方, 藍藻に特徴的な色素としてフィコ ビリンを有しているため，緑色光の利用効率が良いと考 えられている2). 代表的な藍藻に後述するスピルリナが ある。

\section{2 緑藻 (green algae)}

緑藻はいわゆる高等(陸上) 植物と同じ真核生物であ り，葉緑体をもっている。したがって，その光合成では 赤色光と青色光の利用効率が良いと考えられる ${ }^{2)}$. 代表 的な緑藻に後述するクラミドモナスやクロレラがある.

以下では，藍藻と緑藻の生育および物質生産へのLED 
およびLDの適用例を中心に紹介し, その他の藻類や分 野の研究事例もとりあげる.

\section{3. 藍藻の培養へのLEDの利用}

藍藻類の一種であるスピルリナは夕ンパク質を多く含 む栄養補助食品として販売されている. Chenらは, 白 色(380-760 nm), 赤色 (620-645 nm), 黄色 (587-595 nm), 緑色 (515-540 nm) および青色(460-475 nm) のLED光を 750-3000 $\mu \mathrm{mol} /\left(\mathrm{m}^{2} \mathrm{~s}\right)$ で照射した場合のスピルリナ (Spirulina platensis) 中の色素(クロロフィルaおよびフィコシア ニン)含量を調べた。 スピルリナの生育は赤色LEDを用 いた場合が最も良好であったが, 色素含量については青 色LEDを3000 $\mu \mathrm{mol} /\left(\mathrm{m}^{2} \mathrm{~s}\right)$ で照射した場合が最も高く なった。 ただし，この場合はスピルリナの増殖速度の著 しい低下がみられたことから，物質生産性という観点か らは赤色LEDを利用するべきであると結論づけられた³). 前述のように藍藻では, 緑色光の利用効率が高等植物よ りも高いと考えられており，本研究で確かに緑色光によ る生育は青色光よりも良いことが示された。 しかし，そ の場合でもその生育速度は赤色光と比較した場合, $1 / 3$ 程度であっだ)。

藍藻についてはLED利用の研究例がほとんどなく, 現 時点では上記の結果がスピルリナ特有のものなのか藍藻 一般に当てはまるのかは定かでない. 今後, 混合光の利 用や他の藍藻を用いた研究の展開が期待される。

\section{4. 緑藻の培養へのLED·LDの利用}

藍藻と比較して緑藻ではLEDを利用した実験例が多く 存在する. LDを用いた数少ない研究事例として, Kuwahara らは緑藻のモデル生物であるクラミドモナス (Chlamydomonas reinhardtii) の生育に対する赤色 $\mathrm{LD}(650 \mathrm{~nm}$ および $682 \mathrm{~nm})$ および青色固体レーザー $(473 \mathrm{~nm})$ 光照射の影響

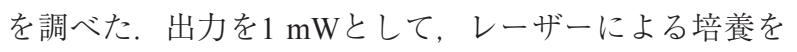
行ったところ, $650 \mathrm{~nm}, 682 \mathrm{~nm}$ い゙れの場合も $473 \mathrm{~nm}$ と同時に照射することによって生育速度が促進された。 その速度はコントロールとした白色の冷㓌極放電ランプ 照射の場合の2倍以上であった ${ }^{4)}$.

同様の混色の効果は緑藻のドナリエラ (Dunaliella sali$n a)$ においても確認されている。 その生育および $\beta$-カ口 テン含量に対して, 赤色 $(660 \mathrm{~nm})$ および青色 $(470 \mathrm{~nm})$ のLED光を3：1で混合した場合に最も高い促進効果が得 られた ${ }^{5)}$ 。また，カロテノイド含量に対する青色LED $470 \mathrm{~nm}$ )の正の効果はへマトコッカス (Heamatococcus pluvialis, アスタキサンチンの生産菌として実用化され ている)においても確認されており ${ }^{6}$, 緑藻に共通の効 果である可能性も考えられる。

Abiusi らはビタミンEを高生産することで知られてい る海洋性微細藻類テトラセルミス(Tetraselmis suecia)に ついて，その生育や成分に与える波長の影響を調べた。 その結果, 白色拈よび赤色 $(640 \mathrm{~nm})$ のLEDを用いた場合 に最も生育が良く，青色(460 nm) および緑色(520 nm)
のLEDを用いた場合には生育速度が半分にまで低下し た。また，赤色LEDでは細胞が小さくなり， クロロフィ ル量が減少することが明らかになった。一方, 青色LED ではクロロフィル量が増加した。 さらに，赤色LEDで生 育した場合，機能性の脂肪酸として知られるエイコサペ ンタエン酸 (EPA) 量が増加することが明らかになった。 最終的に, クロロフィル量の低下や細胞が小さくなるも のの, バイオマスとエイコサペンタエン酸の増加という 点から赤色LEDの利用が有効であると結論づけられ た7).

同様に脂質を高生産させる目的で，Attaらはクロレラ (Chlorella vulgaris)の培養への青色LED(波長未記載)の利 用を検討した。その結果, $200 \mu \mathrm{mol} /\left(\mathrm{m}^{2} \mathrm{~s}\right) て ゙ 12 \mathrm{~h}$ 明期 $/ 12 \mathrm{~h}$ 暗期で培養した場合で最も生育が良く, 脂質含量も高く なることが示された。 また，この際の生育速度は白色蛍 光灯よりも大きかった ${ }^{8)}$ 。また, Nannochloropsis spp. に おいても青色 (470-475 nm) LED光の照射がEPAをはじめ とする脂質の高効率生産に有効であることも示されてい る ${ }^{9)}$. 一方, 酵母との共培養時の油脂の蓄積における波 長の効果についても検討が行われ，この場合には青色お よび緑色 $(550 \mathrm{~nm})$ LEDよりも, 赤色 $(680 \mathrm{~nm})$ LEDの方が 生育および油脂生産能の促進効果が高いことが示されて いる ${ }^{10,11)}$. 油脂生産能の高い緑藻であるボッリオコッカ ス (Botryococcus braunii)では, 脂質生産能に光質の差に よる影響は見られず, 生育速度も勘案した炭化水素の生 産という観点から赤色LED $(660 \mathrm{~nm})$ が最も適しているこ とが示された ${ }^{12)}$.

以上より，生育や脂質の含量に対する各波長の効果は 研究事例毎で異なっており, 現状では緑藻に普遍的な応 答の有無についてはっきりとしたことはいえない. 赤青 混合は生育促進をもたらすことが期待できるが, これに ついても一般化にはより多くの研究結果が必要である.

少し変わった事例として, クロレラを用いたメタンガ ス生産に対するLED光の効果の検証例がある。青色 (460 nm) 黄色 $(590 \mathrm{~nm})$ および白色 (380-760 nm) LED光と 比較して赤色 $(660 \mathrm{~nm})$ LED光を 1200-1600 $\mu \mathrm{mol} /\left(\mathrm{m}^{2} \mathrm{~s}\right)$ で 照射した場合に最も効率良くメタン生産を行えることが 示された13).

\section{5. その他の藻類等の培養へのLEDの利用}

微細藻類だけではなく, 現在, 水産資源として広く利 用されている大型海洋藻類に対しても LED等の人工照明 による生産性増大が期待できる。高田氏らは, 水産上有 用な緑藻であるスジアオノリ(Ulva prolifra)の成長や光 合成に対する異なる波長のLED光照射の影響を解析し た. LED光源として赤色 $(635 \mathrm{~nm})$, 緑色 $(523 \mathrm{~nm})$, 青色 $(470 \mathrm{~nm})$ および白色 $(470 \mathrm{~nm}+560 \mathrm{~nm})$ が用いられた。 その結果, スジアオノリの成長と光合成が青色LED光で 促進され, 緑色LED光では抑制されることが明らかと なった。この結果はスジアオノリの吸収スペクトルから も説明でき，青色LEDと赤色LEDを併用することでさら なる成長促進効果が期待された ${ }^{14)}$ 。この結果は, 微細藻 
類の緑藻で得られている結果と概ね一致する.

同研究グループは褐藻コンブ目のアラメ (Eisenia bicyclis)に対してもスジアオノリと同様の生育試験を実施し ている。その結果, 緑藻のスジアオノリの場合と同様に 青色LED光が有効であることが示された，一方，赤色 LED光でのアラメの成長は遅く, これは, 緑藻と褐藻の 吸収スペクトルの違いに起因すると予測された ${ }^{15)}$ 。すな わち, これらの研究で用いられた赤色LEDの発光スペク トルが610-650 nmであり，スジアオノリはこの波長域に もある程度吸収が見られたものの，アラメでは，この波 長域の吸収が小さいことが明らかとなった。一方，アラ メは緑色光域(490-560 nm) にもフコキサンチン由来の吸 収帯があり，これに対応して緑色光による成長が確認さ れた15)。

以上の結果より, 海藻の生産には青色LEDが有効であ る可能性が示され, 赤色LEDと緑色LEDの利用について は育てる海藻の種類によって使い分けが必要であると考 えらえる。

水産分野において微細藻類は, アコヤガイやカキなど の餌料として利用されている. 石川氏と磯和氏はこの餌 料用微細藻類の培養を白色LEDで行うことを試みた。微 細藻類としてハプト藻類のPavlova lutheriおよび珪藻類 のChaetocreros neogracileを用いたところ, 従来法である 白色蛍光灯で培養した場合と差がないことが示された。 この際，LEDの使用によって消費電力は $50 \%$ にまて削減 され，培養液の温度上昇を抑えられることも利点として 挙げられた ${ }^{16)}$.

藻類とは異なるものの光合成を行う微生物として光合 成細菌が知られている. 光合成細菌にもやはり有用物質 を生産するものがあり, これらを用いた物質生産系の構 築も試みられている. Bertingらは, 嫌気性の紅色光合成 細菌であるRhodobacter capsulatusの培養を, 通信分野等 で広く利用されている $850 \mathrm{~nm}$ の垂直共振器面発光レー ザー(Vertical Cavity Surface Emitting Laser: VCSEL)を用 いて試験的に行った。 その結果, 生育速度や色素成分は 一般的に培養に用いられる白熱電球を使った場合と変わ らず，消費電を30\%低減できることが示された ${ }^{17)} .850 \mathrm{~nm}$ は赤外線であり, 高等植物や藻類が利用できない光であ るという点も興味深い.

\section{6. 環境分野におけるLEDの利用}

藻類は水中の有害物の評価にも用いられる(ISO $8692: 2012$, ISO $10253: 2006$, ISO $14442: 2006)$. この 際，有害物は藻類の生育阻害試験によって定量的に評価 される。このような水質試験においては, 多検体を同時 に測定できるシステムの構築が重要である. Michelと Eisentraegerは, イカダモ(Desmodesmus subspicatus)を白 色LED光照射下, 96穴のマイクロプレート上で200 $\mu \mathrm{L}$ と いう微小スケールで培養し, 得られた結果が従来法と遜 色ないことを示した ${ }^{18)}$.

また, 藻類は海水への酸素供給と適切な栄養塩濃度の 維持などを目的とする水質浄化にも用いられている。た
だし，この効果は夜間には得られず，逆に枯死した藻類 の代謝 · 分解に由来する酸素消費と過剩な栄養塩の流出 が問題となる。山中氏らは尼崎運河の実証実験水路に水 中型白色LED照明を設置し, その水質改善効果を検証し た．その結果，ある程度の効果が得られたが，藻類の光 合成に連続光障害が生じることも確認された。今後，照 射方法を検討することで，より高い水質改善効果が得ら れると期待される ${ }^{19)}$ 。 なお，本試験においては使われて いるLEDが白色のみであるため, 他の波長での効果を検 討するとさらに興味深い結果が得られると思われる.

そのような事例もあり，Kimらは排水中の窒素および リンを除去する目的で, イカダモに白色 (400-560 nm), 赤色 $(670 \mathrm{~nm}$ ), 緑色 (525 nm) および青色 (450 nm) LEDを 照射し, それらの元素の除去能に与える影響を調べた。 強度を $100 \mu \mathrm{mol} /\left(\mathrm{m}^{2} \mathrm{~s}\right)$ に揃え, 種々の条件を検討したと ころ, 赤: 青が7：3の場合に排水からの窒素の除去率が 最大となり，5：5でリンの除去率が最大となることが明 らかとなった ${ }^{20)}$. 排水からの窒素やリンの除去は, 藻類 がこれらの元素を代謝吸収していることを意味する。端 的に述べると，窒素の代謝吸収はタンパク質の合成を， リンの代謝吸収は高エネルギー化合物の合成を意味す る。これらの代謝が異なる光条件で活性化されることは 生理学見地から興味深い現象といえる。

\section{7. おわりに}

ここまで藻類の培養におけるLEDおよびLDの利用に 関する研究成果について概観してきた。冒頭に記載した ように，現状ではそれほど多くの研究事例があるわけで はなく，それぞれの研究も単発的に行われている。例え ば，一口に赤色といっても，実際には610-680 nmでさま ざまな波長の光が用いられており, この範囲でのどの波 長が最も効果的かを調べたような研究事例はほとんどな いといってよい. 同様に一口に微細藻類といっても非常 に多様な種があり，目的とする物質にあわせて生物種を 選択しなければならない状況である。今後も，ここで例 に挙げたような個別研究の蓄積が進むことは予想に難く ないが, 藍藻であればスピルリナ, 緑藻であればクラミ ドモナスといった実験モデル生物種を用いて, 数十 $\mathrm{nm}$ 刻みの波長に対する応答を網羅的に解析するといったよ うな体系的な研究も行う必要があると考えられる。その ような研究は従来大型の分光器を用いて行われてきた が, 複数の波長を照射するような実験系の構築には, 費 用がかかり装置も複雑になる。こういった研究にLEDや LDを利用することで，比較的簡便な実験系の構築が可 能であると考えられる。 今後, それらの研究の結果か ら，どういった現象が各藻類に共通で，どのような物質 生産において個別研究が必要というような情報が整備さ れると考えられる。将来的には, 藻類の各波長の光に対 する応答をきちんと理解した上で, 効率の良い物質生産 系がLEDあるいはLDの利用によって確立されることを 期待したい. 


\section{参考文献}

1) A. Doshi, S. Pascoe, L. Coglan, and T. J. Rainey: Renew. Sust. Energ. Rev. 64 (2016) 329.

2) P. S. C. Schulze, L. A. Barreira, H. G. C. Pereira, J. A. Perales, and J. C. S. Varela: Trends Biotechnol. 32 (2014) 422.

3) H.-B. Chen, J.-Y. Wu, C.-F. Wang, C.-C. Fu, C.-J. Shieh, C.-I. Chen, C.-Y. Wang, and Y.-C. Liu: Biochem. Eng. J. 53 (2010) 52.

4) S. S. Kuwahara, J. L. Cuello, G. Myhre, and S. Pau: Opt. Lasers Eng. 49 (2011) 434.

5) W. Fu, Ó. Guðmundsson, G. Paglia, G. Herjólfsson, Ó. S. Andrésson, B. Ø. Palsson, and S. Brynjólfsson: Appl. Microbiol. Biotechnol. 97 (2013) 2395.

6) T. Katsuda, A. Lababpour, K. Shimahara, and S. Katoh: Enzyme Microb. Technol. 35 (2004) 81.

7) F. Abiusi, G. Sampietro, G. Marturano, N. Biondi, L. Rodolfi, M. D'Ottavio, and M. R. Tredici: Biotehnol. Bioeng. 111 (2014) 956.

8) M. Atta, A. Idris, A. Bukhari, and S. Wahidin: Biores. Technol. 148 (2013) 373

9) C.-Y. Chen, Y.-C. Chen, H.-C. Huang, C.-C. Huang, W.-L. Lee, and J.-S. Chang: Biores. Technol. 147 (2013) 160.

10) C.-H. Shu, C.-C. Tsai, W.-H. Liao, K.-Y. Chen, and H.-C. Huang: J. Chem. Technol. Biotechnol. 87 (2012) 601.

11) P. Das, W. Lei, S. S. Aziz, and J. P. Obbard: Biores. Technol. 102 (2011) 3883.

12) M. Baba, F. Kikuta, I. Suzuki, M. M. Watanabe, and Y. Shiraiwa: Biores. Technol. 109 (2012) 266.

13) Y. Zhao, J. Wang, H. Zhang, C. Yan, and Y. Zhang: Biores. Technol. 136 (2013) 461.

14）高田順司, 村瀬 昇, 阿部 真比古, 野田 幹雄, 須田 有輔 : 水産增殖 59(2011) 101

15）村瀬 昇, 阿部 真比古, 野田 幹雄, 須田 有輔：水産大学研 究報告 62 (2014) 147 .

16) 石川 卓, 磯和 潔：水産技術 4 (2012) 51.

17) K. Bergling, T. J. Hurse, U. Kappler, and A. D. Rakić: Biotechnol. Bioeng. 94 (2006) 337.

18) K. Michel and A. Eisentraeger: Environ. Toxicol. 19 (2004) 609.

19）山中 亮一, 上月 康則, 桶川博教, 沢田 晃聖, 前田 麻里, 沓掛 安宏, 平井 住夫, 一色 圭佑：土木学会論文集 B2(海 岸工学) 68 (2012) I 1166.

20) T.-H. Kim, Y. Lee, S.-H. Han, and S.-J. Hwang: Biores. Technol. 130 (2013) 75. 